\title{
プレキャストコンクリート部材による 建築物の長寿命化
}

\author{
樫 野 紀 元*
}

\section{1.はじめに}

建設工事の合理化や技能者, 労働者の隇少に対応して, 建築のシステム化が進んでいる。その軌を一にして, プ レキャストコンクリート部材を導入した工事の事例が増 加している。

地球環境の保全をはじめ, 経済の低成長路線の継続や 少子化, 高齢化の進展などへの配慮から, 建築物は 100 年耐用を目標とした長寿命とし, 建てては壊しの繰り返 しによる資源の浪費を避け廃棄物の大量排出を抑制する ことが肝要と考えられている。

プレキャストコンクリート部材は, 建築物を長寿命化 するうえでの基本材の一つとして位置づけられるが，部
材間の使い勝手のよいインターフェイスの開発が 1 つの 課題である。

\section{2. 長寿命建築物のプロトタイプ}

建築物を長寿命化するためには，材料部材そのむのの しかるべき耐久性を確保するとともに，建築物の構成を， 製造・施工を合理化するとともにリノベーション（改善 改修）を容易とするよう，スケルトン（柱やはりなど主 要構造部材, サポートともいう）とインフィル（内外装, 間仕切り, 設備機器類など）の分離型建築一SI 建築 （オープンビルディングともいう）一とすることが効果的 である゙。

図-1 は, プレキャストコンクリート部材を導入した

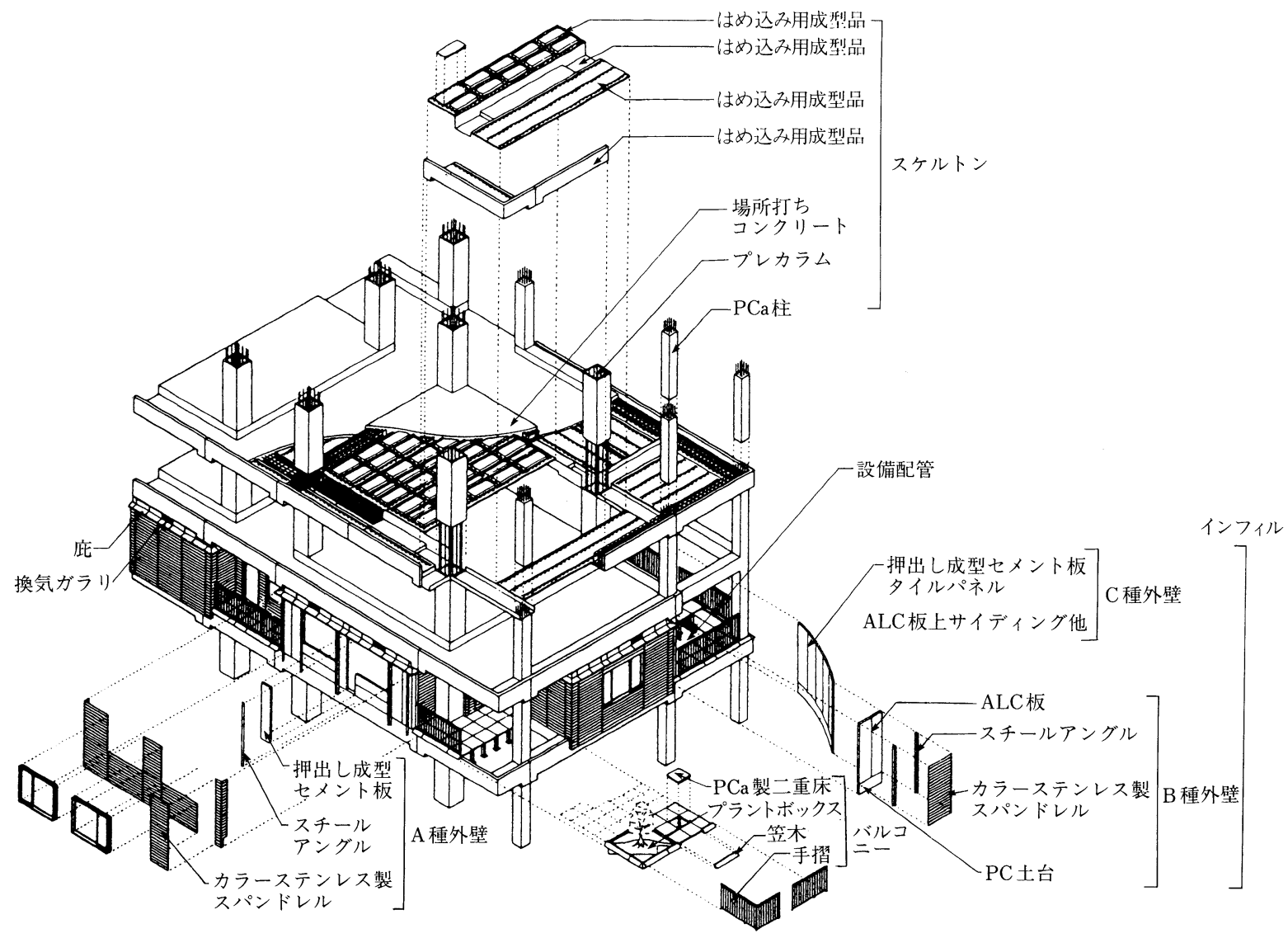

図-1 プレキャストコンクリート部材を導入した SI 建築の例 ${ }^{2)}$ (NEXT 21） 
SI 建築の例である2。。これは，プレキャストコンクリー 卜部材による柱とはりによって躯体骨組みを構成し，そ の間に，それぞれデザインが異なる住居をはめ込む形式 である。ここでは, 住居そのむのをインフィルとして位 置づけている。プレキャスト複合コンクリート工事とす ることにより, 型枠工事を可能な限り省略し, 現場打ち コンクリートによる施工の柔軟性を生かしつつ品質を確 保し軽量化を図っている。

プレキャストコンクリート部材そのものは，所要の強 度を備え，寸法精度や仕上がりが良く，もともと耐久性 に富む。通常の鉄筋コンクリートに比べ，ひび割れが発 生しにくいのも特徴である。タイル先付けなどにより, 仕上げ作業における無足場工事も可能である。

プレキャストコンクリート部材は, SI 建築を構成す るうえで有効と考えられる。

我が国に打ける労働力の需要之供給の見通しは, 図-2 に示すように, 本来必要とする労働力に比へて, 高齢者 や女性を最大限に活用した場合でも労働力人口は減少の 傾向にある。他方, 情報化生産・施工の進展は著しい。

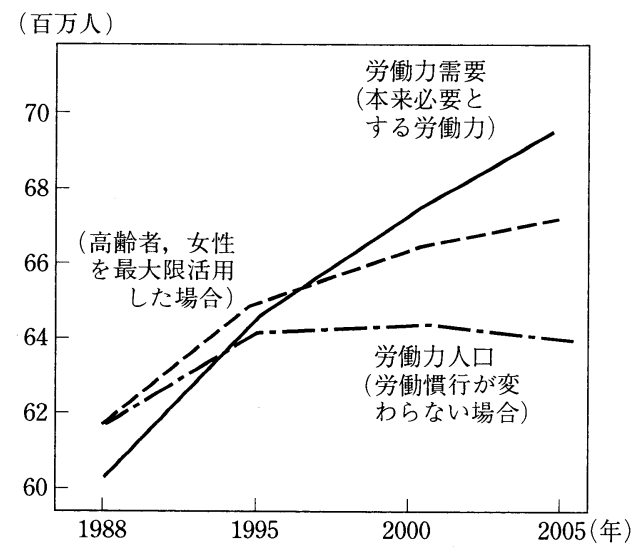

図-2 我が国における労働力需給の見通し [三菱総合研究所資料]

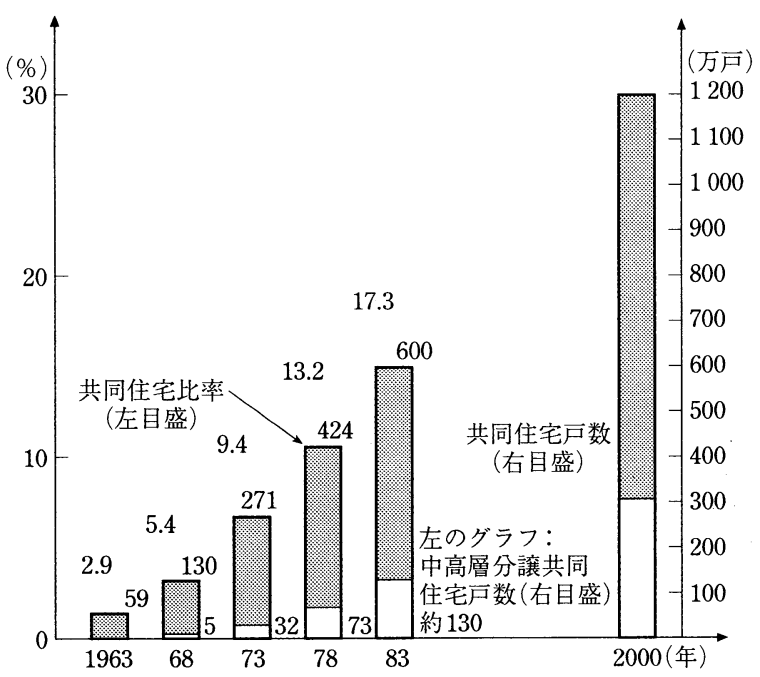

図-3 都市・都市の近郊部における中高層共同住宅戸数の 推移 ${ }^{3)}$ (2000 年は予測)
表-1 PCa 工法と従来の鉄筋コンクリート工事との 建設コスト比較

\begin{tabular}{|c|c|c|c|c|}
\hline & \multicolumn{2}{|c|}{ PCa 工法 } & \multicolumn{2}{|c|}{ 従来の鉄筋コンクリート工事 } \\
\hline & \multicolumn{2}{|c|}{$\begin{array}{c}3 \text { 階, } 2 \text { 棟, } 39 \text { 戸 } \\
\text { 延へ } 3760.6 \mathrm{~m}^{2} \\
1 \text { 戸あたり } 96.42 \mathrm{~m}^{2}\end{array}$} & \multicolumn{2}{|c|}{$\begin{array}{c}3 \text { 階, } 2 \text { 棟, } 41 \text { 戸 } \\
\text { 延べ } 3747.6 \mathrm{~m}^{2} \\
1 \text { 戸あたり } 91.40 \mathrm{~m}^{2}\end{array}$} \\
\hline 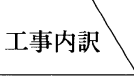 & $\begin{array}{c}\text { 延べ } \mathrm{m}^{2} \text { あたり } \\
\text { 工事費 }\end{array}$ & 係数 & $\begin{array}{c}\text { 延べ } \mathrm{m}^{2} \text { あたり } \\
\text { 工事費 }\end{array}$ & 係数 \\
\hline 仮設工事 & 4794 & 1000 & 9148 & 1908 \\
\hline 躯体工 事 & 24810 & 1000 & 26000 & 1048 \\
\hline 仕上げ工事 & 32906 & 1000 & 49168 & 1494 \\
\hline 設 備 計 & 13307 & 1000 & 22557 & 1690 \\
\hline 諸 経 費 & 25691 & 1000 & 10497 & 1350 \\
\hline 建物本体計 & 81508 & 1000 & 111370 & 1370 \\
\hline
\end{tabular}

（ほかに屋外設備・外構工事があるが，それらについては比較できない）

SI 建築を造る際には，構成材料・部材を部品化，工 場生産化し，現場で機械化施工により組み立てる方式を 取ることが合理的である。この方式は，労働力の減少に 対応しつつも，一定の品質を確保し生産性を向上させる うえで極めて有効であることは論を待たない。

都市や都市の近郊部においては，図-3に示すように， 依然として人口の増加が見られ，中高層の共同住宅の需 要が伸びている3”。

SI 建築ではないが，プレキャストコンクリート部材 の建築物への導入事例は，最近の統計によればタ，1 年 度当たり, 共同住宅が 170 件余である。事務所 40 数件, 工場・倉庫合わせて約 40 件, 体育館 30 数件, 店埔 20 件などと比較して，住宅分野でその導入例が増加してい る。住宅建築には，当然他の材料も使用されているが, プレキャストコンクリート部材の供給実績は, 当然のこ とながら, 都市部における建築需要の傾向と符号してい る。

大規模共同住宅の現場では，サイト工場によるプレキャ ストコンクリート部材の製造が行われるなど，機械化に よる建設工事の利点が生かされている5)。

今後は，プレキャストコンクリート部材による SI 建 築の普及が期待される。

プレキャストコンクリート部材による場合，一般にコ ストが高くなる傾向があるが，生産量やライフサイクル を考慮すれば，表-1に示すように，従来の鉄筋コンク リートによる工事より割安という試算もある6)。

3. 近未来課題としての部材間インターフェイ ス

プレキャストコンクリート部材の部材間接合方式には, ポストテンションの導入や場所打ちコンクリートの打設, 機械接合などがある。構造耐力を確保するため部材を一 体化する工法が採用されるが, 安全性上の問題が解決さ れるならば，機械接合方式がより発展することが望まれ る。

SI 建築とする場合, 部材の組み合わせの自由度が高 いことが望まれ，また工事の合理化も大きな検討対象に 


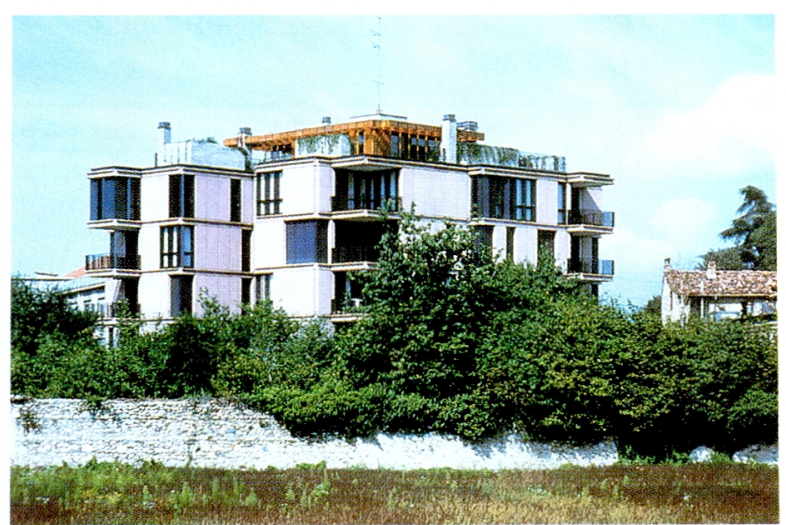

写真-1 アンジェロ・マンジャロッティによるプレキャスト コンクリート部材を用いた共同住宅の例（イタリア一 ミラノ）(写真提供：濱口オサミ氏）

なる。環境問題に対処するうえで屯，可能な限り「部材」 を使い廻せるようにしておくことが肝要である。

このためには，機械接合に対応した，使い勝手のよい インターフェイスを開発することが望まれる。建築物の 標準モデュールの設定屯検討の対象之なろう。

写真-1に示すように, 工場生産品を用いて, 建築に 豊かな表現をむたらせたよいモデルがある。

部材の再利用を考えるならば，補助筋を使用したアン ボンドによるプレストレスト工法の導入が合理的と言わ れている。いずれにしても，現行の法制度の見直しも必
要であろう。

$$
\text { 4. おわりに }
$$

コンクリートそのものは，今後とも建築物を造るため の基幹材料であり続けるであろうが，プレキャストコン クリート部材は，長寿命建築物を実現するための基本的 な要件を具備するものであり，これを用いたプレストレ ストコンクリート造建築物は, これから, 相当の進展が あるものと推察される。

プレキャストコンクリート部材の普及を考えるならば, 普遍的なインターフェイスの開発とモデュラーコーディ ネイションの設定が求められよう。

今後の各方面における積極的な取り組みが期待される。

\section{参考文献}

1）整野紀元：初学者のための建築材料入門, 鹿島出版会, 1998 年 7 月

2）近角真一：NEXT 21 プロジェクトチーム資料

3）樫野紀元編著: 都市亡建築の近未来, 技報堂出版, 1988 年 5 月

4）プレストレスト・コンクリート建設業協会：プレストレストコン クリート, 第 26 報, 1999 年 10 月

5）日本建築学会材料施工部門パネルディスカッション：プレキャス 卜複合コンクリート工事の合理化と問題点一資料, 1999 年 9 月

6）佐久田昌治・整野紀元：日本の住宅を救え, 技術書院, 1999 年 11 月

7）建設省建築研究所・建築業協会・プレストレストコンクリート建 設業協会ほか：PC 構造設計・施工指針の作成一最終年度報告書, 1999 年 3 月

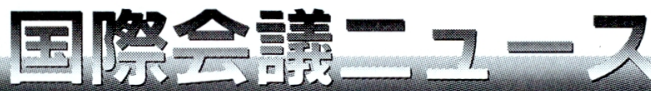

\section{第 16 回 IABSE 国際会議一都市交通施設への取り組み一 \\ 16th Congress of IABSE (Urban Transportation Challenges)}

\author{
日 時： 2000 年 9 月 18 日 21 日 \\ 場 所 : Luzern (Switzerland) \\ 主 催: IABSE \\ 内 容: TECHNICAL PROGRAMME \\ URBAN TRANSPORTATION - NEEDS AND VISIONS \\ Aesthetics $\cdot$ Sustainability and the Environment. \\ Construction Issues in Urban Areas
}

STRUCTURES FOR URBAN TRANSPORTATION Tunnel Design •Bridge Design • Pedestrian Structures $\bullet$ Tunnel Construction $•$ Bridge Construction • Railway Stations $\bullet$ Bridges-Special Cases $\bullet$ Airport Structures $\bullet$ Structures in and on Water

CONSERVATION OF EXISTING STRUCTURES Structural Assessment by Analysis $\bullet$ Assessment by Site Investigation $\cdot$ Structural Repair and Rehabilitation - Strengthening of Structures Management of Existing Structures Information Technology for Infrastructure Management

RECENT LARGE TRANSPORTATION STRUCTURES Alp-Transit $\cdot$ Integrating Copenhagen and Malmö

BASAAR

Briefings about Structural Applications and Research

連絡先: IABSE Secretariat

ETH Höngerberg CH-8093 Zürich, Switzerland Phone +41-1-633 26 47/Fax +41-1-633 1241 e-mail : lucerne@iabse.ethz.ch http.: //www. iabse. ethz.ch 